\title{
Influence of Plant Growth Regulators on Yield and Quality of Seed Guar Varieties
}

\author{
M. Tagore Naik, D. Srihari, A.V.D. Dorajeerao*, K. Sasikala, \\ K. Umakrishna and D.R.S. Suneetha
}
Horticultural Research Station, Mahanandi, College of Horticulture, Venkataramannagudem, Andhra Pradesh, India

*Corresponding author

\begin{tabular}{|c|c|}
\hline & A B S T R A C T \\
\hline Keywords & \multirow{4}{*}{$\begin{array}{l}\text { The seed cluster bean exhibited significant variations in the seed yield and quality due to } \\
\text { spray of growth regulators. At } 90 \text { DAS, the highest seed yield per plant was recorded by } \\
\text { HG } 365 \text {. Among the growth regulators, maximum seed yield per plant was recorded by the } \\
\text { application of CCC at } 1500 \text { ppm which was on par with CCC } 1000 \mathrm{ppm} \text {. The lowest seed } \\
\text { yield per plant was observed by the spray of MC } 500 \mathrm{ppm} \text { preceded by MC } 1000 \mathrm{ppm} \text {. The } \\
\text { crude gum percentage differed significantly due to spray of growth regulators during } \\
\text { kharif and rabi seasons. The maximum crude gum was recorded by HG } 365 \text {. Among the } \\
\text { growth regulators, maximum percentage of crude gum was recorded by the application of } \\
\text { CCC at } 1500 \text { ppm which was on par with CCC } 1000 \mathrm{ppm} \text {. }\end{array}$} \\
\hline $\begin{array}{l}\text { Plant Growth } \\
\text { Regulators, Yield } \\
\text { and quality, Seed } \\
\text { guar }\end{array}$ & \\
\hline Article Info & \\
\hline $\begin{array}{l}\text { Accepted: } \\
\text { 24 May } 2019 \\
\text { Available Online: } \\
\text { 10 June } 2019\end{array}$ & \\
\hline
\end{tabular}

\section{Introduction}

Plant growth regulators (PGR) are known to improve physiological efficiency including photosynthetic ability of plants and offer a significant role in realizing higher crop yields. The PGR's are also known to enhance the source-sink relationship and stimulate the translocation of photo-assimilates, thereby increasing the productivity. Though, the plant growth regulators have great potential, its application and assessment etc. have to be judiciously planned in terms of optimal concentration, stage of application, species specificity and seasons. In their wide spectrum of effectiveness on every aspect of plant growth, even a modest increase of 10-15 per cent could bring about an increment in the gross annual productivity by $10-15 \mathrm{~m}$ tons. The effect of PGRs particular new compounds on cluster bean has not been evaluated and hence the data on this aspect is scarce. Unlike the seeds of other legumes, guar seeds contains sufficient amount of galactomannan gum, which form a viscous gel in cold water. Guar gum has 5-8 times the thickening power of starch. It is used in textile, paper manufacture, stamps, cosmetics, pharmaceuticals, food products, e.g. bakery products, ice cream, stabilizer for cheeses and 
meat binder. Also it is used recently in oil wells, mining industries, explosives, and other industrial applications. Under these conditions, the spray of growth regulating chemicals on partitioning of dry weight among different parts and ultimately the seed yield is studied in the present study.

\section{Materials and Methods}

Seed guar cultivars HG 365 and HG 563 were applied with growth regulating chemicals in a factorial experiment under Mahanandi conditions both during kharif and rabi in the year 2015 to 2017. Foliar sprays of chemicals viz., cycocel, mepiquat chloride and triacontenol were given twice at 20 and 40 days after sowing. Each of these chemicals was tried at three different concentrations i.e. 500, 1000 and $1500 \mathrm{ppm}$. The plants were spaced at $30 \mathrm{~cm} \times 10 \mathrm{~cm}$ and applied with a uniform nutrient dose of $\mathrm{N}$ at $30 \mathrm{~kg} \mathrm{ha}^{-1}+\mathrm{P}$ at $40 \mathrm{~kg} \mathrm{ha}^{-1}+\mathrm{K}$ at $40 \mathrm{~kg} \mathrm{ha}^{-1}+\mathrm{S}$ at $20 \mathrm{~kg} \mathrm{ha}^{-1}$.

\section{Results and Discussion}

\section{Dry pod yield per plant (g) and plot (kg)}

The pod yield per plant and plot (Table 1 and 2) differed significantly due to spray of growth regulators during kharif and rabi seasons. The highest weight of dry pods per plant (kharif $26.19 \mathrm{~g}$; rabi $24.10 \mathrm{~g}$ ) was recorded by $\mathrm{HG}$ 365. Among the growth regulators, maximum weight of dry pods per plant (kharif $28.44 \mathrm{~g}$; rabi $26.17 \mathrm{~g}$ ) was recorded by the application of CCC at 1500 ppm which was on par with CCC 1000 ppm (kharif28.01 g; rabi25.77 g). The highest pod yield per plot (kharif $4.49 \mathrm{~kg}$; rabi $3.80 \mathrm{~kg}$ ) was recorded by HG 365. Among the growth regulators, maximum pod yield per plot (kharif $5.27 \mathrm{~kg}$; rabi $4.46 \mathrm{~kg}$ ) was recorded by the application of $\mathrm{CCC}$ at $1500 \mathrm{ppm}$ which was on par with CCC 1000 ppm (kharif 5.11 $\mathrm{kg}$; rabi4.32 kg). The lowest pod yield per plot was observed by the spray of MC 500 ppm (kharif $3.33 \mathrm{~kg}$; rabi $2.82 \mathrm{~kg}$ ) which was on par with MC 1000 ppm (kharif $3.49 \mathrm{~kg}$; rabi $2.96 \mathrm{~kg}$ ).

The pod yield is the most essential parameter contributing to the seed yield because the only difference lies in pericarps encircling the seeds. The effect of growth regulators was found significant on the pod yield per plant and per plot in both the varieties. As it was observed in case of growth, flowering and quality parameters, the pod yield was found to be highest in case of spray of CCC at 1500 ppm being significantly superior to the same chemical at $1000 \mathrm{ppm}$. The additional concentration beyond $1000 \mathrm{ppm}$ in mepiquat chloride and triacontanol was not resulting in significant superiority in the weight of dry pods per plant as well as per plot. This was not true in case of CCC. The differences in the pod yield or weight of dry pods per plant can be attributed to the similar differences in growth parameters, growth rates and flowering periods as well as pod maturity duration.

Similar observations were made by Prabhavathi (2005) who reported that the application of lihocin (1000 ppm) resulted in significantly higher pod yield followed by miraculan @ 1000 ppm and mepiquat chloride@1000 ppm as compared to control in cluster bean. These effects were attributed to their corresponding effect on growth parameters and growth rates as also evident in the present study.

\section{Seed yield per plant (g) and plot (kg)}

The seed yield per plant and plot (Table 3 and 4) differed significantly due to spray of growth regulators during kharif and rabi seasons. The highest seed yield per plant (kharif $16.88 \mathrm{~g}$; rabi $16.04 \mathrm{~g}$ ) was recorded by HG 365. Among the growth regulators, 
maximum seed yield per plant (kharif 18.33 g; rabi $17.42 \mathrm{~g}$ ) was recorded by the application of CCC at $1500 \mathrm{ppm}$ which was on par with CCC 1000 ppm (kharif $18.05 \mathrm{~g}$; rabi $17.15 \mathrm{~g}$ ). The highest seed yield per plot (kharif $1.85 \mathrm{~kg}$; rabi $1.76 \mathrm{~kg}$ ) was recorded by HG 365. Among the growth regulators, maximum seed yield per plot (kharif $2.01 \mathrm{~kg}$; rabi $1.91 \mathrm{~kg}$ ) was recorded by the application of CCC at $1500 \mathrm{ppm}$ which was on par with CCC 1000 ppm (kharif $1.98 \mathrm{~kg}$; rabi $1.88 \mathrm{~kg}$ ).

Crop yield depend not only on the accumulation of photosynthates during the crop growth and development, but also on its partitioning into the desired storage organs. These in turn, are influenced by the efficiency of metabolic processes within the plant. The growth retardants are capable of redistribution of dry matter in the plant thereby bringing about improvement in yield (Chetti, 1991 and Chandrababuet al., 1995). Similar opinion was expressed by Prabhavathi (2005) who reported that the application of lihocin (1000 ppm) resulted in significantly higher pod yield followed by miraculan@1000 ppm and mepiquat chloride@1000 ppm as compared to control in cluster bean. The increased yield was attributed to higher dry matter production and its accumulation in reproductive parts, higher AGR, CGR and enhanced chlorophyll and nitrate reductase activity.

\section{Pod length $(\mathrm{cm})$}

The pod length (Table 5) differed significantly due to spray of growth regulators during kharifand rabi seasons. The highest pod length (kharif $6.89 \mathrm{~cm}$; rabi $6.34 \mathrm{~cm}$ ) was recorded by $\mathrm{HG}$ 365. Among the growth regulators, maximum pod length (kharif 7.48 $\mathrm{cm}$; rabi $6.89 \mathrm{~cm}$ ) was recorded by the application of $\mathrm{CCC}$ at $1500 \mathrm{ppm}$ which was on par with CCC 1000 ppm (kharif $7.37 \mathrm{~cm}$; rabi $6.78 \mathrm{~cm})$. The lowest pod length was observed by the spray of MC 500 ppm (kharif
$5.95 \mathrm{~cm}$; rabi $5.48 \mathrm{~cm}$ ) which was on par with MC 1000 ppm (kharif $6.10 \mathrm{~cm}$; rabi5.61 cm).

\section{Pod width (cm)}

The pod width (Table 6) differed significantly due to spray of growth regulators during kharif and rabi seasons. The highest pod width (kharif $1.31 \mathrm{~cm}$; rabi $1.20 \mathrm{~cm}$ ) was recorded by $\mathrm{HG}$ 365. Among the growth regulators, maximum pod width (kharif 1.42 $\mathrm{cm}$; rabi $1.31 \mathrm{~cm}$ ) was recorded by the application of CCC at $1500 \mathrm{ppm}$ which was on par with CCC 1000 ppm (kharif $1.40 \mathrm{~cm}$; rabi $1.29 \mathrm{~cm})$. The lowest pod width was observed by the spray of MC 500 ppm (kharif $1.13 \mathrm{~cm}$; rabi $1.04 \mathrm{~cm}$ ) which was on par with MC 1000 ppm (kharif $1.16 \mathrm{~cm}$; rabi $1.07 \mathrm{~cm}$ ).

\section{Hundred seed weight (g)}

The hundred seed weight (Table 7) differed significantly due to spray of growth regulators during kharif and rabi seasons. The highest hundred seed weight (kharif $3.05 \mathrm{~g}$; rabi 2.81 g) was recorded by $\mathrm{HG}$ 365. Among the growth regulators, maximum hundred seed weight (kharif $3.20 \mathrm{~g}$; rabi $2.94 \mathrm{~g}$ ) was recorded by the application of CCC at 1500 ppm which was on par with CCC 1000 ppm (kharif $3.15 \mathrm{~g}$; rabi $2.90 \mathrm{~g}$ ). The lowest hundred seed weight was observed by the spray of MC $500 \mathrm{ppm}$ (kharif $2.55 \mathrm{~g}$; rabi $2.34 \mathrm{~g}$ ) which was on par with MC $1000 \mathrm{ppm}$ (kharif $2.61 \mathrm{~g}$; rabi $2.40 \mathrm{~g}$ ).

The pod and seed quality parameters in terms of size, weight, number of seeds and test weight were found to vary significantly due to growth regulator sprays in both the varieties under study. The best quality heavier pods with greater length and width as well as more number of seeds with higher individual seed weight were produced from the variety $\mathrm{HG}$ 365 as compared to HG 563 which may be a varietal character and also due to contribution 
from an enlarged duration of time taken from flowering to pod drying on the plants.

Similar points were noted in the investigations made by Mishriky et al., (1990) who reported that there was significant increase in the number and weight of pods and the total yield in peas due to the application of CCC (500 ppm). The highest number of green pods per plant in pea was observed in the treatment with CCC at 200 ppm which was attributed due to the corresponding increase in the dry matter accumulation and early flowering coupled with extended period spent in pod maturation as explained by Mishriky et al., (1990). These results are in conformity with above findings. In chick pea, Arora et al., (1998) observed that there was increase in number of pods, number of seeds, seed size and yield per plant due to application of cycocel (chloremquat) at 50 per cent flowering stage.

Sharma and Lashkari (2009) obtained maximum number of tender pods per plant, length and width of pods, volume of pods and total crude protein content with the application of CCC $1000 \mathrm{ppm}$. While the highest seed yield was recorded by CCC 2000 ppm. The probable reasons for enhanced length, width and volume of pod might be due to greater accumulation of carbohydrates by photosynthetic activity which might have helped in increasing carbohydrates content of pods and responsible for pod development and seed yield. It was observed that at all concentrations of cycocel significantly increased total crude protein content of pods.

The maximum increase in the values of pod numbers and size due to the application of triacontanol and mepiquat chloride was felt to be due to more number of pods and large sized green pods as well as increased vegetative growth and balanced $\mathrm{C} / \mathrm{N}$ ratio, which might have increased the synthesis of carbohydrates ultimately leading to greater growth and yield. It has been also reported that, the secretions of hormones like IAA, cytokinin, auxin and GA at higher levels of photosynthetic surface in plants, might have been another factor for increasing the yield. The above results corroborates with Brown et al., (1993).

\section{Crude protein $(\%)$}

The crude protein (\%) (Table 8) differed significantly due to spray of growth regulators during kharif and rabi seasons. The highest crude protein (kharif 26.41; rabi 24.29) was recorded by $\mathrm{HG}$ 365. Among the growth regulators, maximum crude protein (kharif 25.71 ; rabi 23.65) was recorded by the application of CCC at $1500 \mathrm{ppm}$ which was on par with CCC 1000 ppm (kharif 25.59; rabi 23.54). The lowest crude protein was observed by the spray of MC 500 ppm (kharif 23.71; rabi 21.82) which was on par with MC 1000 ppm (kharif 23.95; rabi 22.03).

It is inferred from the results on nitrate reductase activity and crude protein that both of them were dependent or associated together. Higher the nitrate reductase activity higher was the crude protein content and vice versa. Thus in the present study both these values were recorded at maximum level by the variety HG 365 and the spray of CCC at $1500 \mathrm{ppm}$. The enzyme nitrate reductase helps in the assimilation of nitrate nitrogen into the plants and therefore it might help in higher nitrogen content in various plant parts making it available for the biosynthesis of protein molecules. This might be the reason as to why a higher activity of nitrate reductase as observed in the best combination of treatments of growth regulator spray had led to a higher content of crude protein. However, it was observed that both the activity of enzyme and content of protein did not increase significantly with increase in the 
concentration of growth regulators spray beyond $1000 \mathrm{ppm}$ thus making the effect of additional amount of chemical null and void in majority of the cases. The highest concentration of CCC was significantly superior to the highest concentration of triacontanol which was on par with the lowest concentration of CCC. However, the highest concentration of mepiquat chloride was not on par with the lowest concentration of triacontanol.

The enzyme nitrate reductase catalyzes the reduction of nitrate to nitrite and is a rate limiting step in the nitrogen metabolism (Beevers and Hageman, 1969). It was observed that the activity of nitrate reductase increased significantly with the application of growth regulators. The study by Prabhavathi (2005) revealed that nitrate reductase activity was maximum at 40 DAS in the genotype
DWD-1 (local) but Pusa Naubahar had maximum nitrate reductase activity at 60 DAS. The treatment lihocin (1000 ppm) recorded significantly higher nitrate reductase activity followed by miraculan (1000 ppm).

Similarly, Lawlor and Fock (1975) suggested that CCC induced increase in photosynthesis was associated with an increase in the enzyme activity and nucleic acid metabolism. CCC was also reported to increase cytokinin content in leaves leading to higher chlorophyll content (Skene, 1968). Possibly, CCC induced higher NRA and chlorophyll content may be due to the combination of various factors cited above, which in turn manifest the final yield. Similarly, Sivakumaret al., (2002) also reported that foliar application of triacontanol @ 10 ppm increased the nitrate reductase activity in pearl millet.

Table.1 Dry pod yield per plant (g) as influenced by growth regulators in cluster bean varieties during kharif and rabi

\begin{tabular}{|c|c|c|c|c|c|c|}
\hline \multirow{3}{*}{$\begin{array}{l}\text { Growth regulators (ppm) } \\
\text { (B) }\end{array}$} & \multicolumn{6}{|c|}{ Variety (A) } \\
\hline & \multicolumn{3}{|c|}{ Kharif } & \multicolumn{3}{|c|}{ Rabi } \\
\hline & HG 365 & HG 563 & Mean & HG 365 & HG 563 & Mean \\
\hline CCC 500 & 27.23 & 24.49 & 25.86 & 25.05 & 22.53 & 23.79 \\
\hline CCC 1000 & 29.49 & 26.53 & 28.01 & 27.13 & 24.41 & 25.77 \\
\hline CCC 1500 & 29.95 & 26.94 & 28.44 & 27.55 & 24.78 & 26.17 \\
\hline MC 500 & 23.82 & 21.43 & 22.62 & 21.92 & 19.71 & 20.81 \\
\hline MC 1000 & 24.39 & 21.94 & 23.16 & 22.44 & 20.18 & 21.31 \\
\hline MC 1500 & 24.50 & 22.04 & 23.27 & 22.54 & 20.28 & 21.41 \\
\hline TRIA 500 & 24.96 & 22.45 & 23.70 & 22.96 & 20.65 & 21.81 \\
\hline TRIA 1000 & 27.23 & 24.49 & 25.86 & 25.05 & 22.53 & 23.79 \\
\hline TRIA 1500 & 27.68 & 24.90 & 26.29 & 25.46 & 22.90 & 24.18 \\
\hline Control & 22.69 & 19.82 & 21.25 & 20.87 & 18.24 & 19.55 \\
\hline Mean & 26.19 & 23.50 & 24.85 & 24.10 & 21.62 & 22.86 \\
\hline Factor & $S E m \pm$ & \multicolumn{2}{|c|}{$C D$} & $S E m \pm$ & \multicolumn{2}{|c|}{$C D$} \\
\hline Variety $(A)$ & 0.032 & \multicolumn{2}{|c|}{0.09} & 0.029 & \multicolumn{2}{|c|}{0.08} \\
\hline Growth regulators $(B)$ & 0.160 & \multicolumn{2}{|c|}{0.46} & 0.147 & \multicolumn{2}{|c|}{0.42} \\
\hline Interaction $(A \quad x \quad B)$ & - & \multicolumn{2}{|c|}{$N S$} & - & \multicolumn{2}{|c|}{$N S$} \\
\hline
\end{tabular}

CD: CD at 5\% level of significance CCC: Cycocel MC: Mepiquat chloride TRIA: Triacontanol 
Table.2 Dry pod yield per plot $(\mathrm{kg})$ as influenced by growth regulators in cluster bean varieties during kharif and rabi

\begin{tabular}{|c|c|c|c|c|c|c|c|}
\hline \multirow{3}{*}{$\begin{array}{l}\text { Growth regulators (ppm) } \\
\text { (B) }\end{array}$} & \multicolumn{6}{|c|}{ Variety (A) } & \\
\hline & \multicolumn{3}{|c|}{ Kharif } & \multicolumn{3}{|c|}{ Rabi } & \\
\hline & HG 365 & HG 563 & Mean & HG 365 & HG 563 & Mean & \\
\hline CCC 500 & 4.81 & 3.89 & 4.35 & 4.07 & 3.30 & 3.68 & \\
\hline CCC 1000 & 5.65 & 4.57 & 5.11 & 4.78 & 3.87 & 4.32 & \\
\hline CCC 1500 & 5.82 & 4.71 & 5.27 & 4.93 & 3.99 & 4.46 & \\
\hline MC 500 & 3.69 & 2.98 & 3.33 & 3.12 & 2.52 & 2.82 & \\
\hline MC 1000 & 3.86 & 3.13 & 3.49 & 3.27 & 2.65 & 2.96 & \\
\hline MC 1500 & 3.90 & 3.15 & 3.53 & 3.30 & 2.67 & 2.98 & \\
\hline TRIA 500 & 4.04 & 3.27 & 3.66 & 3.42 & 2.77 & 3.10 & \\
\hline TRIA 1000 & 4.81 & 3.89 & 4.35 & 4.07 & 3.30 & 3.68 & \\
\hline TRIA 1500 & 4.97 & 4.02 & 4.50 & 4.21 & 3.41 & 3.81 & \\
\hline Control & 3.34 & 2.55 & 2.95 & 2.83 & 2.16 & 2.49 & \\
\hline Mean & 4.49 & 3.62 & 4.05 & 3.80 & 3.06 & 3.43 & \\
\hline Factor & $S E m \pm$ & \multicolumn{2}{|c|}{$C D$} & $S E m \pm$ & \multicolumn{2}{|c|}{$C D$} & \\
\hline $\operatorname{Variety}(A)$ & 0.010 & \multicolumn{2}{|c|}{0.03} & 0.009 & \multicolumn{2}{|c|}{0.03} & \\
\hline Growth regulators $(B)$ & 0.052 & \multicolumn{2}{|c|}{0.15} & 0.044 & \multicolumn{2}{|c|}{0.13} & \\
\hline Interaction $(A x \quad B)$ & 0.059 & \multicolumn{2}{|c|}{0.17} & 0.050 & \multicolumn{2}{|c|}{0.14} & \\
\hline
\end{tabular}

CD: CD at 5\% level of significance CCC: Cycocel MC: Mepiquat chloride TRIA: Triacontanol

Table.3 Seed yield per plant (g) as influenced by growth regulators in cluster bean varieties during kharif and rabi

\begin{tabular}{|c|c|c|c|c|c|c|c|}
\hline \multirow{3}{*}{ Growth regulators (B) } & \multicolumn{6}{|c|}{ Variety (A) } & \\
\hline & \multicolumn{3}{|c|}{ Kharif } & \multicolumn{3}{|c|}{ Rabi } & \\
\hline & HG 365 & HG 563 & Mean & HG 365 & HG 563 & Mean & \\
\hline CCC 500 & 17.55 & 15.78 & 16.67 & 16.67 & 14.99 & 15.83 & \\
\hline CCC 1000 & 19.01 & 17.10 & 18.05 & 18.06 & 16.24 & 17.15 & \\
\hline CCC 1500 & 19.30 & 17.36 & 18.33 & 18.34 & 16.49 & 17.42 & \\
\hline MC 500 & 15.35 & 13.81 & 14.58 & 14.59 & 13.12 & 13.85 & \\
\hline MC 1000 & 15.72 & 14.14 & 14.93 & 14.93 & 13.43 & 14.18 & \\
\hline MC 1500 & 15.79 & 14.20 & 15.00 & 15.00 & 13.49 & 14.25 & \\
\hline TRIA 500 & 16.09 & 14.47 & 15.28 & 15.28 & 13.74 & 14.51 & \\
\hline TRIA 1000 & 17.55 & 15.78 & 16.67 & 16.67 & 14.99 & 15.83 & \\
\hline TRIA 1500 & 17.84 & 16.05 & 16.94 & 16.95 & 15.24 & 16.10 & \\
\hline Control & 14.62 & 12.78 & 13.70 & 13.89 & 12.14 & 13.01 & \\
\hline Mean & 16.88 & 15.15 & 16.01 & 16.04 & 14.39 & 15.21 & \\
\hline Factor & $S E m \pm$ & \multicolumn{2}{|c|}{$C D$} & $S E m \pm$ & \multicolumn{2}{|c|}{$C D$} & \\
\hline Variety $(A)$ & 0.02 & \multicolumn{2}{|c|}{0.06} & 0.02 & \multicolumn{2}{|c|}{0.06} & \\
\hline Growth regulators $(B)$ & 0.10 & \multicolumn{2}{|c|}{0.30} & 0.10 & \multicolumn{2}{|c|}{0.28} & \\
\hline Interaction $(A \quad x \quad B)$ & 0.12 & \multicolumn{2}{|c|}{0.34} & 0.11 & \multicolumn{2}{|c|}{0.32} & \\
\hline
\end{tabular}

CD: CD at 5\% level of significance CCC: Cycocel MC: Mepiquat chloride TRIA: Triacontanol 
Table.4 Seed yield per plot $(\mathrm{kg})$ as influenced by growth regulators in cluster bean varieties during kharif and rabi

\begin{tabular}{|c|c|c|c|c|c|c|c|}
\hline \multirow{3}{*}{$\begin{array}{l}\text { Growth regulators (ppm) } \\
\text { (B) }\end{array}$} & \multicolumn{6}{|c|}{ Variety (A) } & \\
\hline & \multicolumn{3}{|c|}{ Kharif } & \multicolumn{3}{|c|}{ Rabi } & \\
\hline & HG 365 & HG 563 & Mean & HG 365 & HG 563 & Mean & \\
\hline CCC 500 & 1.92 & 1.73 & 1.82 & 1.82 & 1.64 & 1.73 & \\
\hline CCC 1000 & 2.08 & 1.87 & 1.98 & 1.98 & 1.78 & 1.88 & \\
\hline CCC 1500 & 2.11 & 1.90 & 2.01 & 2.01 & 1.81 & 1.91 & \\
\hline MC 500 & 1.68 & 1.51 & 1.60 & 1.60 & 1.44 & 1.52 & \\
\hline MC 1000 & 1.72 & 1.55 & 1.63 & 1.63 & 1.47 & 1.55 & \\
\hline MC 1500 & 1.73 & 1.55 & 1.64 & 1.64 & 1.48 & 1.56 & \\
\hline TRIA 500 & 1.76 & 1.58 & 1.67 & 1.67 & 1.50 & 1.59 & \\
\hline TRIA 1000 & 1.92 & 1.73 & 1.82 & 1.82 & 1.64 & 1.73 & \\
\hline TRIA 1500 & 1.95 & 1.76 & 1.85 & 1.85 & 1.67 & 1.76 & \\
\hline Control & 1.60 & 1.40 & 1.50 & 1.52 & 1.33 & 1.42 & \\
\hline Mean & 1.85 & 1.66 & 1.75 & 1.76 & 1.57 & 1.67 & \\
\hline Factor & $S E m \pm$ & \multicolumn{2}{|c|}{$C D$} & $S E m \pm$ & \multicolumn{2}{|c|}{$C D$} & \\
\hline Variety $(A)$ & 0.00 & \multicolumn{2}{|c|}{0.01} & 0.00 & \multicolumn{2}{|c|}{0.01} & \\
\hline Growth regulators (B) & 0.01 & \multicolumn{2}{|c|}{0.03} & 0.01 & \multicolumn{2}{|c|}{0.03} & \\
\hline Interaction $(A x \quad B)$ & 0.01 & \multicolumn{2}{|c|}{0.04} & 0.01 & \multicolumn{2}{|c|}{0.04} & \\
\hline
\end{tabular}

CD: $\mathrm{CD}$ at $5 \%$ level of significance CCC: Cycocel MC: Mepiquat chloride TRIA: Triacontanol

Table.5 Pod length (cm) as influenced by growth regulators in cluster bean varieties during kharif and rabi

\begin{tabular}{|c|c|c|c|c|c|c|}
\hline \multirow{3}{*}{$\begin{array}{c}\text { Growth regulators (ppm) } \\
\text { (B) }\end{array}$} & \multicolumn{6}{|c|}{ Variety (A) } \\
\hline & \multicolumn{3}{|c|}{ Kharif } & \multicolumn{3}{|c|}{ Rabi } \\
\hline & HG 365 & HG 563 & Mean & HG 365 & HG 563 & Mean \\
\hline CCC 500 & 7.16 & 6.44 & 6.80 & 6.59 & 5.93 & 6.26 \\
\hline CCC 1000 & 7.76 & 6.98 & 7.37 & 7.14 & 6.42 & 6.78 \\
\hline CCC 1500 & 7.88 & 7.09 & 7.48 & 7.25 & 6.52 & 6.89 \\
\hline MC 500 & 6.27 & 5.64 & 5.95 & 5.77 & 5.19 & 5.48 \\
\hline MC 1000 & 6.42 & 5.77 & 6.10 & 5.90 & 5.31 & 5.61 \\
\hline MC 1500 & 6.45 & 5.80 & 6.12 & 5.93 & 5.34 & 5.63 \\
\hline TRIA 500 & 6.57 & 5.91 & 6.24 & 6.04 & 5.43 & 5.74 \\
\hline TRIA 1000 & 7.16 & 6.44 & 6.80 & 6.59 & 5.93 & 6.26 \\
\hline TRIA 1500 & 7.28 & 6.55 & 6.92 & 6.70 & 6.03 & 6.36 \\
\hline Control & 5.97 & 5.22 & 5.59 & 5.49 & 4.80 & 5.15 \\
\hline Mean & 6.89 & 6.18 & 6.54 & 6.34 & 5.69 & 6.02 \\
\hline Factor & $S E m \pm$ & \multicolumn{2}{|c|}{$C D$} & $S E m \pm$ & \multicolumn{2}{|c|}{$C D$} \\
\hline Variety $(A)$ & $0.00 \overline{8}$ & \multicolumn{2}{|c|}{0.02} & $0.00 \overline{8}$ & \multicolumn{2}{|c|}{0.02} \\
\hline Growth regulators $(B)$ & 0.042 & \multicolumn{2}{|c|}{0.12} & 0.039 & \multicolumn{2}{|c|}{0.11} \\
\hline Interaction $(A \quad x \quad B)$ & - & \multicolumn{2}{|c|}{$N S$} & - & \multicolumn{2}{|c|}{$N S$} \\
\hline
\end{tabular}

CD: $\mathrm{CD}$ at $5 \%$ level of significance CCC: Cycocel MC: Mepiquat chloride TRIA: Triacontanol 
Table.6 Pod width $(\mathrm{cm})$ as influenced by growth regulators in cluster bean varieties during kharif and rabi

\begin{tabular}{|c|c|c|c|c|c|c|}
\hline \multirow{3}{*}{$\begin{array}{c}\text { Growth regulators (ppm) } \\
\text { (B) }\end{array}$} & \multicolumn{6}{|c|}{ Variety (A) } \\
\hline & \multicolumn{3}{|c|}{ Kharif } & \multicolumn{3}{|c|}{ Rabi } \\
\hline & HG 365 & HG 563 & Mean & HG 365 & HG 563 & Mean \\
\hline CCC 500 & 1.36 & 1.22 & 1.29 & 1.25 & 1.13 & 1.19 \\
\hline CCC 1000 & 1.47 & 1.33 & 1.40 & 1.36 & 1.22 & 1.29 \\
\hline CCC 1500 & 1.50 & 1.35 & 1.42 & 1.38 & 1.24 & 1.31 \\
\hline MC 500 & 1.19 & 1.07 & 1.13 & 1.10 & 0.99 & 1.04 \\
\hline MC 1000 & 1.22 & 1.10 & 1.16 & 1.12 & 1.01 & 1.07 \\
\hline MC 1500 & 1.23 & 1.10 & 1.16 & 1.13 & 1.01 & 1.07 \\
\hline TRIA 500 & 1.25 & 1.12 & 1.19 & 1.15 & 1.03 & 1.09 \\
\hline TRIA 1000 & 1.36 & 1.22 & 1.29 & 1.25 & 1.13 & 1.19 \\
\hline TRIA 1500 & 1.38 & 1.24 & 1.31 & 1.27 & 1.15 & 1.21 \\
\hline Control & 1.13 & 0.99 & 1.06 & 1.04 & 0.91 & 0.98 \\
\hline Mean & 1.31 & 1.18 & 1.24 & 1.20 & 1.08 & 1.14 \\
\hline Factor & $S E m \pm$ & \multicolumn{2}{|c|}{$C D$} & $S E m \pm$ & \multicolumn{2}{|c|}{$C D$} \\
\hline Variety $(A)$ & 0.002 & \multicolumn{2}{|c|}{0.00} & 0.001 & \multicolumn{2}{|c|}{0.00} \\
\hline Growth regulators (B) & 0.008 & \multicolumn{2}{|c|}{0.02} & 0.007 & \multicolumn{2}{|c|}{0.02} \\
\hline Interaction $(A \times x)$ & - & \multicolumn{2}{|c|}{$N S$} & - & \multicolumn{2}{|c|}{$N S$} \\
\hline
\end{tabular}

CD: $\mathrm{CD}$ at $5 \%$ level of significance CCC: Cycocel MC: Mepiquat chloride TRIA: Triacontanol

Table.7 Hundred seed weight (g) as influenced by growth regulators in cluster bean varieties during kharif and rabi

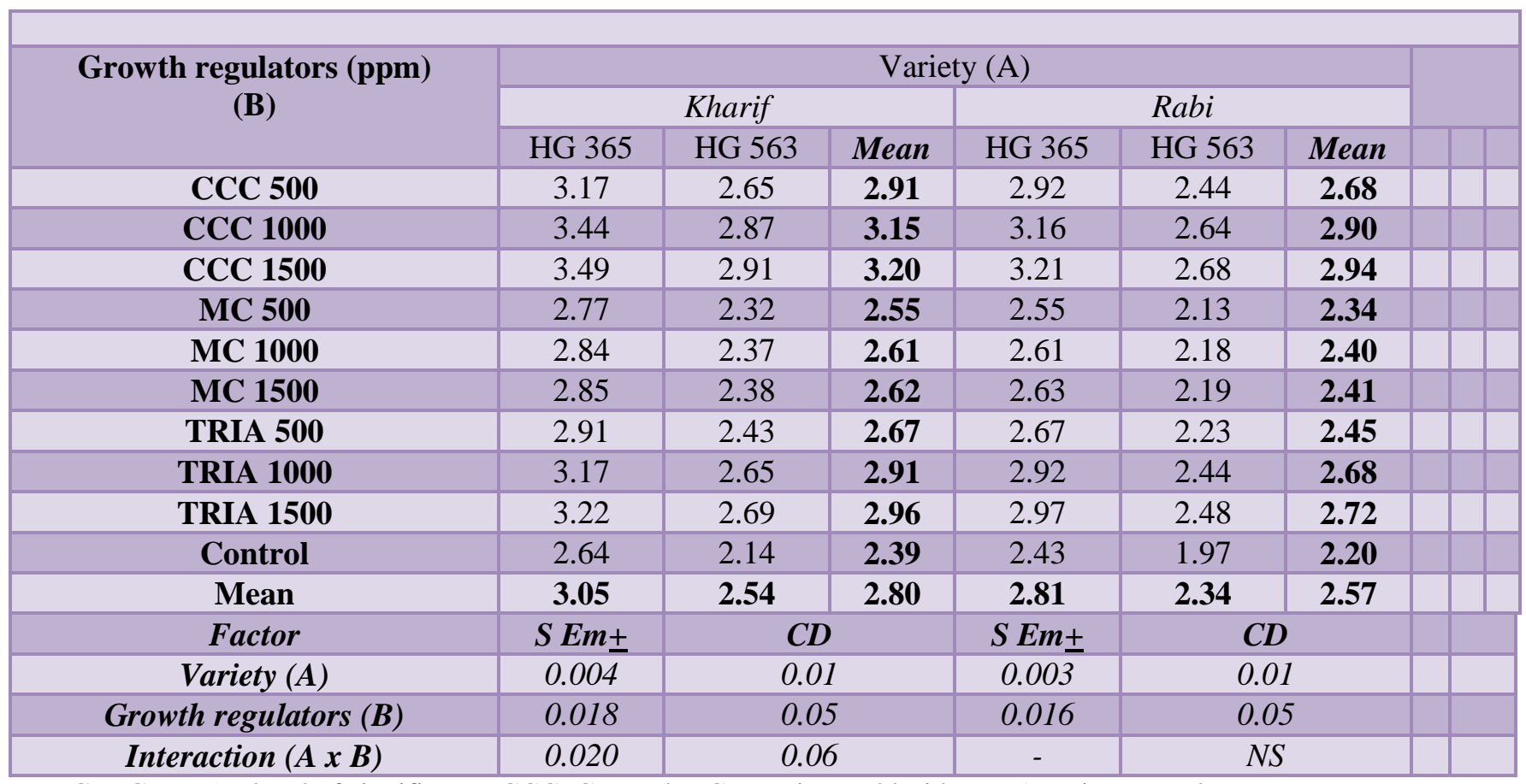

CD: $\mathrm{CD}$ at $5 \%$ level of significance CCC: Cycocel MC: Mepiquat chloride TRIA: Triacontanol 
Table.8 Crude protein (\%) as influenced by growth regulators in cluster bean varieties during kharif and rabi

\begin{tabular}{|c|c|c|c|c|c|c|}
\hline \multirow{3}{*}{$\begin{array}{c}\text { Growth regulators (ppm) } \\
\text { (B) }\end{array}$} & \multicolumn{6}{|c|}{ Variety (A) } \\
\hline & \multicolumn{3}{|c|}{ Kharif } & \multicolumn{3}{|c|}{ Rabi } \\
\hline & HG 365 & HG 563 & Mean & HG 365 & HG 563 & Mean \\
\hline CCC 500 & 27.11 & 23.60 & 25.36 & 24.94 & 21.71 & 23.33 \\
\hline CCC 1000 & 27.36 & 23.82 & 25.59 & 25.17 & 21.91 & 23.54 \\
\hline CCC 1500 & 27.49 & 23.93 & 25.71 & 25.29 & 22.01 & 23.65 \\
\hline MC 500 & 25.35 & 22.07 & 23.71 & 23.32 & 20.31 & 21.82 \\
\hline MC 1000 & 25.60 & 22.29 & 23.95 & 23.56 & 20.51 & 22.03 \\
\hline MC 1500 & 25.86 & 22.51 & 24.18 & 23.79 & 20.71 & 22.25 \\
\hline TRIA 500 & 26.36 & 22.95 & 24.65 & 24.25 & 21.11 & 22.68 \\
\hline TRIA 1000 & 26.86 & 23.38 & 25.12 & 24.71 & 21.51 & 23.11 \\
\hline TRIA 1500 & 26.98 & 23.49 & 25.24 & 24.83 & 21.61 & 23.22 \\
\hline Control & 25.10 & 21.85 & 23.48 & 23.09 & 20.10 & 21.60 \\
\hline Mean & 26.41 & 22.99 & 24.70 & 24.29 & 21.15 & 22.72 \\
\hline Factor & $S E m \pm$ & \multicolumn{2}{|c|}{$C D$} & $S E m \pm$ & \multicolumn{2}{|c|}{$C D$} \\
\hline Variety $(A)$ & $0.01 \overline{1}$ & \multicolumn{2}{|c|}{0.03} & 0.010 & \multicolumn{2}{|c|}{0.03} \\
\hline Growth regulators (B) & 0.054 & \multicolumn{2}{|c|}{0.16} & 0.050 & \multicolumn{2}{|c|}{0.15} \\
\hline Interaction $(A x \quad B)$ & - & \multicolumn{2}{|c|}{$N S$} & - & \multicolumn{2}{|c|}{$N S$} \\
\hline
\end{tabular}

CD: $\mathrm{CD}$ at $5 \%$ level of significance CCC: Cycocel MC: Mepiquat chloride TRIA: Triacontanol

Table.9 Crude gum (\%) as influenced by growth regulators in cluster bean varieties during kharif and rabi

\begin{tabular}{|c|c|c|c|c|c|c|}
\hline \multirow[t]{3}{*}{ Growth regulators (B) } & \multicolumn{6}{|c|}{ Variety (A) } \\
\hline & \multicolumn{3}{|c|}{ Kharif } & \multicolumn{3}{|c|}{ Rabi } \\
\hline & HG 365 & HG 563 & Mean & HG 365 & HG 563 & Mean \\
\hline CCC 500 & 31.97 & 29.98 & 30.98 & 29.69 & 28.00 & 28.85 \\
\hline CCC 1000 & 32.23 & 30.21 & 31.22 & 29.93 & 28.21 & 29.07 \\
\hline CCC 1500 & 32.36 & 30.33 & 31.35 & 30.05 & 28.32 & 29.19 \\
\hline MC 500 & 30.12 & 28.38 & 29.25 & 27.99 & 26.52 & 27.26 \\
\hline MC 1000 & 30.38 & 28.60 & 29.49 & 28.23 & 26.73 & 27.48 \\
\hline MC 1500 & 30.65 & 28.83 & 29.74 & 28.48 & 26.94 & 27.71 \\
\hline TRIA 500 & 31.18 & 29.29 & 30.24 & 28.96 & 27.37 & 28.17 \\
\hline TRIA 1000 & 31.70 & 29.75 & 30.73 & 29.45 & 27.79 & 28.62 \\
\hline TRIA 1500 & 31.83 & 29.87 & 30.85 & 29.57 & 27.89 & 28.73 \\
\hline Control & 31.38 & 29.47 & 30.43 & 29.15 & 27.53 & 28.34 \\
\hline Mean & 31.97 & 29.98 & 30.98 & 29.69 & 28.00 & 28.85 \\
\hline Factor & $S E m \pm$ & \multicolumn{2}{|c|}{ CD at $5 \%$} & $S E m \pm$ & \multicolumn{2}{|c|}{ CD at $5 \%$} \\
\hline $\operatorname{Variety}(A)$ & $0.01 \overline{1}$ & \multicolumn{2}{|c|}{0.03} & $0.01 \overline{1}$ & \multicolumn{2}{|c|}{0.03} \\
\hline Growth regulators $(B)$ & 0.057 & \multicolumn{2}{|c|}{0.17} & 0.053 & \multicolumn{2}{|c|}{0.15} \\
\hline Interaction $\left(A \begin{array}{lll}\boldsymbol{x} & B\end{array}\right)$ & - & \multicolumn{2}{|c|}{$N S$} & - & \multicolumn{2}{|c|}{$N S$} \\
\hline
\end{tabular}

CD: CD at 5\% level of significance CCC: Cycocel MC: Mepiquat chloride TRIA: Triacontanol 


\section{Crude gum (\%)}

The crude gum (\%) (Table 9) differed significantly due to spray of growth regulators during kharif and rabi seasons. The highest crude gum (kharif $31.97 \%$; rabi $29.69 \%$ ) was recorded by HG 365. Among the growth regulators, maximum crude gum (kharif 31.35 $\%$; rabi29.19 \%) was recorded by the application of CCC at $1500 \mathrm{ppm}$ which was on par with CCC 1000 ppm (kharif $31.22 \%$; rabi $29.07 \%$ ). TRIA resulted in the moderate value during both the seasons (kharif 30.85 $\%$, rabi $28.73 \%$ ). The lowest crude gum was observed by the spray of MC 500 ppm (kharif $29.25 \%$; rabi $27.26 \%$ ) which was on par with MC $1000 \mathrm{ppm}$ (kharif $29.49 \%$; rabi $27.48 \%)$.

The content of crude gum in the seed governs the value of the guar produce since the gum is the product of export value. The cultivar HG 365 exhibited the highest gum content and among the growth regulators sprays, CCC at $1500 \mathrm{ppm}$ exhibited the highest gum content being the one having the bold sized seeds from significantly robust pods and clusters. The individual plant being capable of drawing more nutrients over an extended period of duration spent in building up of vegetative frame work and on the other hand prolonged reproductive period. Such a plant also exhibited better pod quality parameters and therefore was also able to produce seeds with a higher content of galactomannan. The sprays of CCC and triacontanol at $1500 \mathrm{ppm}$ were found on par with $1000 \mathrm{ppm}$, thus making the effect of additional amount of chemicals non-significant in increasing gum content of individual seeds. The highest effect in positive direction in increasing gum content was observed by the spray of CCC followed by triacontanol and mepiquat chloride. The highest concentration of traicontanol $(1500 \mathrm{ppm})$ was found on par with the lowest concentration of CCC (500 ppm) but the same was not true between mepiquat chloride and triacontanol.

\section{References}

Arora, N, Balwinder Kaur, Parmil Singh, Usha Parmar, Kaur, B. Singh, P. and Parmar, U. 1998. Effect of IAA and cycocel on yield contributing parameters of chickpea (Cicer arietinum L.). Annals of Agricultural Research. 19 (3): 279-81.

Beevers, L. and Hageman, R. H. 1969. Nitrate reduction in higher plants. Annual Review of Plant Physiology. 20: 495522.

Brown, J. E, Gillian, C. H. and Shumack, R. L. 1993. Commercial snap bean response to Growth Regulators. Horticultural Science. 25: 29-31.

Chandrababu, R, Manian, K, Nagarajan, M. and Ramachandran, T. K. 1995. Effect of mepiquat chloride on growth and yield of groundnut. Madras Agricultural Journal. 82 (3): 229-30.

Chetti, M. B. 1991. Evaluation of chamatkar on groundnut. Pestology. 15: 43-50.

Lawlor, D. W. and Fock, H. 1975. Photosynthesis and photo respiratory $\mathrm{CO}_{2}$ evolution of water stressed sunflower leaves. Planta. 126: 38187.

Mishriky, J. F, El-Fadaly, K. A. and Badawi, M. A. 1990. Effect of gibberellic acid $\mathrm{GA}_{3}$ and chloromequat $\mathrm{CCC}$ on growth yield and quality of peas (PisumsativumL.). Bulletin of Faculty of Agriculture. 41 (3): 785-97.

Prabhavathi, V. H. 2005. Effect of plant growth regulators, organics and nutrients on growth, physiology and yield in cluster bean (Cyamopsis tetragonoloba L.Taub.). M.Sc. (Agri.) Thesis. University of Agricultural Sciences, Dharwad.

Sharma, S. J. and Lashkari, C. O. 2009. Effect 
of plant growth regulators on yield and quality of Clusterbean (Cyamopsis tetragonaloba L.) cv. 'Pusa Navbahar'. The Asian Journal of Horticulture. 4 (1): 145-46.

Skene, K. G. M. 1968. Increase in cytokinin in bleeding sap of Vitis vinifera L. after CCC treatment. Science. 159:
1477-78.

Sivakumar, R, Pathmanaban, G, KalaranI, M. K, Mallika, V. and Srinivasan, P. S. 2002. Effect of foliar application of growth regulators on biochemical attributes and grain yield in pearl millet. Indian Journal of Plant Physiology. 7 (1): 79-82.

\section{How to cite this article:}

Tagore Naik, M., D. Srihari, A.V.D. Dorajeerao, K. Sasikala, K. Umakrishna and Suneetha, D.R.S. 2019. Influence of Plant Growth Regulators on Yield and Quality of Seed Guar Varieties. Int.J.Curr.Microbiol.App.Sci. 8(06): 3004-3014. doi: https://doi.org/10.20546/ijcmas.2019.806.358 